\title{
DEGREE OF PROTEINURIA IN POST-ICTERIC STATE OF HEPATITIS E VIRUS (HEV) INFECTED PATIENTS
}

\author{
Nargis $\mathrm{W}^{1}$, Ahamed $\mathrm{BU}^{2}$, Zabeen $\mathrm{S}^{3}$, Alam $\mathrm{F}^{4}$, Wahab $\mathrm{MA}^{5}$, Arslan $\mathrm{MI}^{6}$
}

\begin{abstract}
Introduction: Nephropathies, as one of the multiple extrahepatic features of Hepatitis $E$ virus (HEV) infection, can occur in clinically improved HEV hepatitis patients which in majority of the cases remain clinically silent for a long period. By the time these are reported, patients have already developed renal insufficiency which may even lead to renal replacement therapy. Proteinuria, a simple test in practice, can be a useful tool for early detection of the underlying renal impairment.

Objective: The aim of this study was to detect the presence of proteinuria and to evaluate the degree of proteinuria in HEV- hepatitis patients during post-icteric state.

Materials and Methods: This cross sectional study was conducted on 50 diagnosed patients of clinically improved HEV-hepatitis at the Department of Biochemistry, Bangabandhu Sheikh Mujib Medical University (BSMMU) with active cooperation of the Department of Hepatology, BSMMU, between July 2006 and June 2007. Cases were chosen carefully, to exclude the acute state of illness and the patients of HEV were selected during their third or fourth follow-up, in their post-icteric phase. The study subjects were grouped according to equal age ranges in group-I (18-26 year) and group-II (27-35 year). Depending on the level of spot urinary protein $(\mathrm{mg} / \mathrm{dl})$ the subjects were also categorized as having trace, mild and moderate proteinuria.
\end{abstract}

Results: The mean age of $\mathrm{HEV}$ infected subjects was $24.72 \pm 2.59$ years. The mean spot urinary protein in age group-II patients was raised compared to age group-I and the difference was highly significant $(\mathbf{p}<\mathbf{0 . 0 0 1})$. Moreover, there was no significant difference $(p>0.05)$ of spot urinary protein of male and female. Majority of HEV patients $(42 \%)$ presented with mild proteinuria and mostly (53.3\%) was of age group-I.

Conclusion: Spot urinary protein concentration should be checked in every HEV- hepatitis patient to detect the presence and level of proteinuria.

Keywords: Proteinuria, Hepatitis E virus (HEV), nephropathy

\section{Introduction}

Hepatitis E virus (HEV) is one of the common causes of non-A, non-B hepatitis (NANBH) identified in developing countries like Bangladesh ${ }^{1-3}$. HEV usually causes self-limited acute viral hepatitis in adults aged between 15-40 years, but fatal outcome is observed in up to $20 \%$ of cases in pregnant women ${ }^{3}$. Though important advances have been made in prevention of viral hepatitis, no effective vaccine is available against $\mathrm{HEV}^{4,5}$. $\mathrm{HEV}$ infection is associated with a wide range of extrahepatic features, including renal disease. Such HEV patients may present with proteinuria in their post-icteric phase which can be detected during their third or fourth follow-up. Hepatitis itself can cause proteinuria which usually subsides within the first week of jaundice ${ }^{6,7}$. Thus HEV infection, though self limiting, patients should be seen 34 weeks after discharge, and if necessary at monthly intervals for next 3 months $^{8,9}$. A simple test for monitoring proteinuria is in practice and can be a useful tool for early detection of the underlying renal impairment to halt further disease progression and for effective interventions.

Proteinuria, an increased urinary excretion of protein, in people with a normal glomerular filtration rate (GFR), is associated with an increase in adverse clinical outcomes, even when excretion of protein is as low as $7 \mathrm{mg} /$ day $^{10}$. The method most commonly used to measure urinary protein relies on 24-hour urine collection, which is the gold standard but is time consuming, cumbersome, and often inaccurate and imprecise. An alternative approach, avoiding timed urine collection is the measurement of the protein and creatinine ratio in single random urine specimen $^{11}$. But the ratio is influenced by urinary creatinine excretion, which can vary considerably among individuals ${ }^{12}$. Hence a spot urine examination for protein would be more acceptable and less time consuming ${ }^{13}$. A number of studies done in different countries have related proteinuria in $\mathrm{HEV}$ infections with impending renal impairment. This study was undertaken to detect

1. Dr Waheeda Nargis MBBS, M Phil, Associate Professor, Department of Biochemistry, Uttara Adhunik Medical College, Dhaka; 2. Dr Borhan Uddin Ahamed MBBS, Assistant Registrar, Department of Surgery, Uttara Adhunik Medical College, Dhaka; 3. Dr Shahana Zabeen MBBS, MD, Assistant Professor, Department of Biochemistry, Anwer Khan Medical College, Dhaka; 4. Dr Farhana Alam MBBS, M Phil, Associate Professor, Department of Biochemistry, Dhaka Community Medical College; 5. Maj Md Abdul Wahab MBBS, MD, Assistant Professor, Department of Biochemistry, AFMC; 6. Prof M Iqbal Arslan MBBS, M Phil, Chairman, Department of Biochemistry, BSMMU. 
the presence of proteinuria and also to evaluate the degree of proteinuria in $\mathrm{HEV}$ - hepatitis patients.

\section{Materials and Methods}

This study was conducted at the Department of Biochemistry, Bangabandhu Sheikh Mujib Medical University (BSMMU), Dhaka, with active cooperation of the Department of Hepatology, BSMMU, between July 2006 and June 2007. A total of 50 diagnosed cases of HEV hepatitis patients were selected purposively on the basis of history, physical examination and laboratory findings. The non smoker and non alcoholic subjects with positive anti-HEV antibody were included in this study. Cases were chosen carefully, to exclude the acute state of illness. Patients of HEV were selected during their third or fourth follow-up, in their post-icteric phase. After taking informed written and verbal consent from the study subjects they were duly instructed and advised for sample collection. The random spot urine specimens were collected along with $5 \mathrm{ml}$ of blood to conduct all the relevant tests. The specimens were stored appropriately until analyzed. HEV hepatitis patients with raised fasting plasma glucose (for diabetes), total bilirubin (acute hepatitis), alanine aminotransferase (for acute state of illness), triglyceride, total cholesterol (for dyslipidaemia, acute glomerulonephritis, nephritic syndrome), serum creatinine and decreased creatinine clearance (for pre-existing renal impairment) and with raised blood pressure (for hypertension) were excluded.

The study subjects were grouped in group-I (18-26 year) and group-II (27-35 year). They were also categorized according to the level of spot urinary protein $(\mathrm{mg} / \mathrm{dl})$. The spot urinary protein was measured by Pyrogallol red molybdate method ${ }^{14}$. The spot urinary protein $\leqslant 10 \mathrm{mg} / \mathrm{dl}$ was defined as trace or normal, 11-30 mg/dl as mild proteinuria, $31-100 \mathrm{mg} / \mathrm{dl}$ as moderate and $\geqslant 101 \mathrm{mg} / \mathrm{dl}$ as heavy proteinuria ${ }^{15}$.

All the collected raw data were organized into statistical format by using SPSS 12.0 for windows software. All the continuous data were expressed as mean $\pm \mathrm{SD}$ and categorical data in percentage (\%) and frequency (f). Unpaired ' $t$ ' test was done to see the significance between the groups. For all statistical analyses 'p' values $<0.05$ were considered as significant.

\section{Results}

Total 50 patients of HEV induced viral hepatitis were selected as subjects for the evaluation of degree of proteinuria. The mean $\pm \mathrm{SD}$ of age of $\mathrm{HEV}$ infected subjects was $24.72 \pm 2.59$ years and the range was between 18-35 years. Of the selected subjects 35 were in group I and 15 were in group II. There was highly significant difference $(\mathrm{p}<0.01)$ of spot urinary protein between the age groups of HEV hepatitis (Table-I).
Table-I: Comparison of spot urinary protein in different age groups of the HEV study subjects

\begin{tabular}{|l|l|l|l|}
\hline Group & $\begin{array}{l}\text { Spot urinary } \\
\text { protein }[\mathbf{m g} / \mathbf{d}]\end{array}$ & t value & p value \\
\cline { 1 - 2 } I $(\mathrm{n}=35)$ & $17.73 \pm 05.675$ & 3.195 & $<0.001$ \\
\cline { 1 - 2 } II $(\mathrm{n}=15)$ & $30.66 \pm 15.140$ & & \\
\hline All cases $(\mathrm{n}=50)$ & $26.78 \pm 14.285$ & & \\
\hline
\end{tabular}

Out of 50 study subjects 26 (52\%) were male and 24 (48\%) were females. According to the age groups, the age group-I include 17 (48.6\%) males and 18 (51.4\%) females, age group-II with 09 (60\%) males and 06 (40\%) females. Various results and analysis are shown in following tables:

Table-II: Comparison of spot urinary protein of male and female in different age groups

\begin{tabular}{|l|l|l|l|l|}
\hline Group & Sex & $\begin{array}{l}\text { Spot urinary } \\
\text { protein }(\mathbf{m g} / \mathbf{d l})\end{array}$ & t-value & p-value \\
\hline \multirow{2}{*}{ I } & Male $(\mathrm{n}=17)$ & $16.67 \pm 5.22$ & 0.305 & $>0.05$ \\
\cline { 2 - 3 } & Female $(\mathrm{n}=18)$ & $19.33 \pm 6.439$ & & \\
\hline \multirow{2}{*}{ II } & Male $(\mathrm{n}=09)$ & $31.47 \pm 13.034$ & 0.885 & $>0.05$ \\
\cline { 2 - 4 } & Female $(\mathrm{n}=06)$ & $29.89 \pm 17.242$ & & \\
\hline \multirow{2}{*}{$\begin{array}{l}\text { All } \\
\text { Cases }\end{array}$} & Male $(\mathrm{n}=26)$ & $26.35 \pm 13.001$ & 0.221 & $>0.05$ \\
\cline { 2 - 3 } & Female $(\mathrm{n}=24)$ & $27.25 \pm 15.829$ & & \\
\hline
\end{tabular}

Table-III: Frequency distribution of degree of spot urinary protein in different age groups of HEV- study subjects

\begin{tabular}{|l|l|l|l|}
\hline $\begin{array}{l}\text { Proteinuria } \\
{[\mathbf{m g} / \mathbf{d l}]}\end{array}$ & $\begin{array}{l}\text { Group-I } \\
\mathbf{f}(\%)\end{array}$ & $\begin{array}{l}\text { Group-II } \\
\mathbf{f}(\%)\end{array}$ & $\begin{array}{l}\text { Total } \\
\mathbf{f}(\%)\end{array}$ \\
\hline Trace $(\leqslant 10)$ & $01(2.85)$ & $02(13.3)$ & $03(06)$ \\
\hline Mild (11-30) & $13(37.14)$ & $08(53.3)$ & $21(42)$ \\
\hline Moderate (31-100) & $21(60.01)$ & $05(33.3)$ & $26(52)$ \\
\hline Total & 35 & 15 & 50 \\
\hline
\end{tabular}

Table-IV: Frequency distribution of degree of spot urinary protein in male and female of HEV- study subjects

\begin{tabular}{|l|l|l|l|}
\hline $\begin{array}{l}\text { Proteinuria } \\
{[\mathbf{~ m g} / \mathbf{d l}]}\end{array}$ & $\begin{array}{l}\text { Male } \\
\mathbf{f ( \% )}\end{array}$ & $\begin{array}{l}\text { Female } \\
\mathbf{f}(\mathbf{\%})\end{array}$ & $\begin{array}{l}\text { Total } \\
\mathbf{f}(\mathbf{\%})\end{array}$ \\
\hline Trace $(\leqslant 10)$ & $02(66.60 \%)$ & $01(33.30 \%)$ & $03(100 \%)$ \\
\hline Mild $(11-30)$ & $08(38.09 \%)$ & $13(61.90 \%)$ & $21(100 \%)$ \\
\hline Moderate $(31-100)$ & $16(61.53 \%)$ & $10(38.46 \%)$ & $26(100 \%)$ \\
\hline Total & 26 & 24 & 50 \\
\hline
\end{tabular}

\section{Discussion}

In this study, the mean proteinuria in middle age group (27 to 35 years) was significantly higher $(\mathrm{p}<0.001)$ than the early age group (18 to 26 year) of HEV study subjects. Similar findings were reported by a number studies $^{16-18}$, whereas, this observation was inconsistent 
with Hamid et al, who demonstrated the association of HEV-related renal disorders with higher degree of proteinuria among young adults ${ }^{19}$. This difference may be explained as the unequal number of patients in different age groups and the smaller sample size of this study.

In this study, the male to female ratio was almost equal (1.08:1). The Mean spot urinary protein in male and female showed no significant difference $(\mathrm{p}>0.05)$ in any age group. However, younger male patients showed higher $(31.47 \pm 13.034 \mathrm{mg} / \mathrm{dl})$ mean spot urinary protein. Majority (52\%) of $\mathrm{HEV}$ patients had moderate proteinuria and $42 \%$ presented with mild proteinuria. These findings were not consistent with some studies where mild proteinuria was reported in majority of the cases $^{16,19,20}$, but was consistent with the finding of Verschuuren et $\mathrm{al}^{21}$.

The prevalence of proteinuria in HEV patients was 94\%, with majority $(52 \%)$ of moderate and $42 \%$ of mild proteinuria. Here, majority of the younger male cases $(57.69 \%)$ demonstrated moderate proteinuria and where maximum younger females (52.38\%) showed mild proteinuria, though the male to female ratio in different degree of proteinuria was very close. Epidemiological studies have shown that in some individuals [particularly children] HEV infection leads to the development of nephritic syndrome with strong male predominance which is also reflected in this study but it's not supported by Irshad $\mathrm{M}^{22}$. Present study revealed that trace proteinuria was mostly associated with elderly male HEV subjects in age group II $(66.6 \%)$ followed by mild proteinuria $(28.57 \%)$. But such observations may vary between continents and regions due to the marked differences in the epidemiology of HEV infection4. Such inconsistency of this study probably can be minimized by larger sample size.

Therefore, it is observed in this study that the difference of spot urinary protein among the different age groups of HEV patients was highly significant $(p<0.001)$. The elderly age group had higher rate and degree of proteinuria than the early age groups. The male hepatitis patients showed higher spot urinary protein in comparison to the female though it is statistically insignificant.

\section{Conclusion}

The spot urinary protein concentration should be checked in every HEV hepatitis patient, especially in elderly males, to detect the presence and level of proteinuria. Patients of HEV should be monitored for proteinuria even after recovery for early detection and intervention.

\section{References}

1. Labrique AB, Thomas DL, Stoszek SK, Nelson KE. Hepatitis E: an emerging infectious disease. Epidemiol Rev 1999; 21: 162-179.

2. Labrique AB, Zaman K, Hossain Z, et al. Population Seroprevalence of Hepatitis E Virus Antibodies in Rural Bangladesh. Am J Trop Med Hyg 2009; 81(5): 875-881.

3. Khan WI. Viral hepatitis: recent experiences from serological studies in Bangladesh. Asian Pac J Allergy Immunol 2000; 18(2) : 99-103.

4. Sherilock S. Viral Hepatitis: General Features, Hepatitis A, Hepatitis E and Other Viruses, Disease of The Liver And Biliary System 12th edn. UK: Blackwell scientific publications; 2002 .p. 267-284.

5. Bower WA, Nainan OV, Han X, Margolis HS. Duration of viraemia in hepatitis A virus infection. J Infect Dis 2000; 182(1):12-7.

6. Klar A. Hepatitis A Associated with other Focal Infections. IMAJ 2000; 2:598 - 599.

7. Tagle M. Relapsing viral hepatitis type A complicated with renal failure. Rev Gastroenterol Peru 2004; 24(1): 92-6

8. Conaty S, Bird P, Bell G, Kraa E, Grohmann G, McAnulty JM. Hepatitis A in New South Wales, Australia, from consumption of oysters: the first reported outbreak. Epidemiol Infect 2000; 124: 121130.

9. Yoshikawa N, Kitagawa K, Ohta K, Tanaka R, Nakamura H. Asymptomatic constant isolated proteinuria in children. J Pediatr 1991; 119: 375-379.

10. Tonelli M, Jose P, Curhan G, Sacks F, Braunwald E, Pfeffer M. Proteinuria, impaired kidney function, and adverse outcomes in people with coronary disease: analysis of a previously conducted randomized trial. BMJ 2006; 332(7555): 1426.

11. Ruggenenti I, Gaspari F, Perna A, Remuzzi G. Cross sectional longitudinal study of spot morning urine protein:creatinine ratio, 24 hour urine protein excretion rate, glomerular filtration rate, and end stage renal failure in chronic renal disease in patients without diabetes. BMJ 1998; 316(7130): 504.

12. Rathi DP, Bansal RC, Malhotra KK. Spot urine test for quantitative estimation of proteinuria. J Assoc Phy Ind 1985; 33: 781.

13. Agarwal I, Kirubakaran C. Markandeyulu and Selvakumar, Quantitation of Proteinuria by Spot Urine Sampling. Indian Journal of Clinical Biochemistry 2004; 19 (2):45-47.

14. Watanabe N, Kamel S, Ohkobo A, et al. Urinary Protein as Measured with a Pyrogallol Red-Molybdate Complex, Manually and in a Hitachi 726 Automated Analyser. Clinical Chemistry 1986; 32 (8): 1551-1554.

15. Keane WF. Proteinuria: Its clinical importance and role in progressive renal disease. Am J Kidney Dis 2000; 35 :(suppl 1), S97S105.

16. Ali G, Kumar M, Bali SK, Wadhwa WB. Hepatitis E associated immune thrombocytopaenia and membranous glomerulonephritis. Indian J Nephrol 2001; 11:70-72.

17. Dash SC and Bhowmik D. Glomerular lesions in liver disorders. Indian Journal of Nephrology 2001; 177-181.

18. Sheikh A, Sugitani M, Kinukawa N, et al. Hepatitis E virus infection in fulminant hepatitis patients and an apparently healthy population in Bangladesh. Am J Trop Med Hyg 2002; 66(6): 721-4.

19. Hamid SS, Atiq M, Shehzad F, et al. Hepatitis E virus superinfection in patients with chronic liver disease. Hepatology 2002;36, pp. 474-8.

20. Kamar N, Mansuy JM, Esposito L, et al. Acute hepatitis and renal function impairment related to infection by hepatitis $\mathrm{E}$ virus in a renal allograft recipient. Am J Kidney Dis 2005; 45(1) :193-6.

21. Verschuuren EAM, Hacysma EB, Zijlstra JG, et al. Nonoliguric acute renal failure associated with hepatitic E. Nephrol Dial Transplant 1997; 12: 799-801.

22. Irshad M. Hepatitis E virus: A global view of its seroepidemiology and transmission pattern. Trop Gastroenterol 1997; 18: 45-49. 